\title{
Corneal Thickness and Endothelial Morphology in Normal Thai Eyes
}

Napaporn Tananuvat ( $\square$ ntananuvat@gmail.com )

Chiang Mai University Faculty of Medicine https://orcid.org/0000-0003-4124-9163

Natawan Khumchoo

Western University Department of Ophthalmology

\section{Research article}

Keywords: Corneal endothelium, specular microscopy, central corneal thickness, corneal endothelial cell density

Posted Date: January 20th, 2020

DOI: https://doi.org/10.21203/rs.2.21265/v1

License: @ (i) This work is licensed under a Creative Commons Attribution 4.0 International License. Read Full License

Version of Record: A version of this preprint was published at BMC Ophthalmology on April 28th, 2020. See the published version at https://doi.org/10.1186/s12886-020-01385-1. 


\section{Abstract}

Background: This study aimed to determine the influence of age on central corneal thickness and corneal endothelial morphology as well as to identify the relationship between them in normal Thai eyes.

Methods: Non-contact specular microscopy was performed in volunteers stratified into seven age groups ranging from 11-88 years. The corneal endothelial parameters studied included central corneal thickness (CCT), endothelial cell density (ECD), coefficient of variation in cell size (CV), cell area (CA) and percentage of regular hexagonal cells.

Results: In a total of 501 subjects (1002 eyes), the mean age was $43.12 \pm 18.80$ years and 347(69.3\%) were females. The mean CCT, ECD, CV, CA, and hexagonality was $533.80 \pm 33.00 \mu \mathrm{m}, 2,732 \pm 258 \mathrm{cell} / \mathrm{mm}^{2}, 37.61 \pm 6.76 \%, 369.04 \pm 37.90 \mathrm{~mm}$, and $49.03 \% \pm 7.53 \%$, respectively. There was a statistically significant inverse correlation between age and CCT $(r=-0.212, P<0.001)$, ECD $(r=-0.484, P<0.001)$, and hexagonality $(r=-0.193, P<0.001)$. The estimate rate of endothelial cell loss was $0.2 \%$ per year, whereas CV and CA had statistically significant correlation with age $(r=0.200, P<0.001$ and $r=0.475, P$ $<0.001)$. CCT correlated directly with ECD $(r=0.177, \mathrm{P}<0.001)$.

Conclusion: Normative data for corneal endothelial morphology in healthy Thai eyes showed that ECD, CCT, and hexagonality were significantly decreased, while CV and CA were increased with aging. The central corneal thickness was correlated with the endothelial cell density.

\section{Background}

Corneal endothelial cells (CECs), originated from the neural crest, cover the posterior surface of the cornea and are made up of a monolayer of interdigitated cells arranged in a mosaic pattern of mostly hexagonal shapes [1].These metabolically active cells are responsible for regulating fluid and solute transport between the aqueous humor and corneal stromal in order to maintain normal corneal thickness and corneal transparency [2]. Unlike the corneal epithelia, the CECs cannot regenerate and decline throughout their life [2,3]. Other factors that contribute to alteration of CECs morphology include trauma [2], intraocular surgery [4], contact lens wearing [5], dry eye [6], and systemic diseases such as diabetes mellitus [7].

In order to compensate the cell loss, the surrounding CECs will be enlarged, thus wound healing is accomplished by spreading of cells to create a contiguous layer of cells on the inner surface of the cornea [2]. Apart from endothelial cell density, the coefficient of variation of the mean cell area (standard deviation of mean cell area/ mean cell area) is a clinically valuable marker and is about 0.25 in the normal cornea. This increase in the variation of cell size is termed as polymegathism. Another indication of CEC health is a percentage of hexagonality. In the normal healthy cornea, $70-80 \%$ of CECs have a hexagonal shape. This deviation from hexagonality is referred to as pleomorphism [8].

Corneal thickness is another important parameter for diagnosis of corneal disorders and treatment plan. Corneal thickness becomes more essential in determining intraocular pressure (IOP) [9]. Increased corneal thickness may give an artificially high IOP measurement, while decreased corneal thickness may give an underestimated IOP reading.

The specular microscope is a tool to assess the structure and functions of corneal endothelial cells in vivo. Currently, a non-contact specular microscope is widely used to evaluate the corneal endothelial morphology because it is non-invasive and easy to perform.

The study of corneal thickness and corneal endothelial cell morphology is needed for evaluating the cornea health. However, the results have been found to be different among various populations. Normative data are necessary for comparison between normal populations and in patients with eye diseases as well as in planning for intraocular surgery, corneal transplantation and refractive procedures, such as phakic intraocular lenses, and to study the effects of new intraocular devices or topical drugs. This study aimed to evaluate the correlation of age on central corneal thickness and corneal endothelial morphology in normal Thai eyes in different age groups, and to be used as normative data for further studies.

\section{Methods}

This prospective cross-sectional study was based in the outpatient eye clinic, Chiang Mai University Hospital, tertiary eye care in northern Thailand, between May 2016 and March 2018. This study was approved from the Research and Ethics Committee of Faculty of Medicine, Chiang Mai University (Study code: OPT-2559-03823) and followed the tenets of Declaration of Helsinki. Written informed consent was obtained from all the participants and from a parent or guardian for participants under 16 years old after complete explanation.

Inclusion criteria were as follows: volunteers age more than ten years who were walk-in patients or volunteers from staffs or relatives of the patients with Thai ethnicity and nationality. Exclusion criteria included glaucoma or using anti-glaucoma medications, corneal disorders (i.e. scar, ectasia, and dystrophy), pterygium that involved cornea $>2 \mathrm{~mm}$, recent ocular infection, previous ocular surgery or ocular trauma, history of contact lens wear, and refractive errors with spherical equivalent beyond \pm 6 diopters. The subjects were also excluded if having systemic conditions that may affect the cornea such as diabetes mellitus. Elderly subjects who had age-related cataract with best corrected visual acuity (VA) of $\geq 6 / 18$ were recruited if the other parts of the eyes were normal.

Complete ocular examination was performed in all subjects including Snellen VA, IOP assessment, auto-refraction, slit-lamp biomicroscopy, and fundus examination. Non-contact specular microscopy (EM4000, Tomey Corporation, Nagoya, Japan) was used to evaluate the central corneal thickness and corneal endothelium morphology. The device provides continuous capturing 16 images with the one-time operation. The best quality image is automatically selected and analysis of cell parameter was performed by the built-in software, and the results were displayed on the screen and obtained as the printout. 
The main corneal endothelial parameters in this study were central corneal thickness (CCT), endothelial cell density (ECD), coefficient of variation in average cell size (CV), cell area (CA) and percentage of regular hexagonal cells (hexagonality). Volunteers were divided into seven groups of allocation by stratified age. Each group included a 10-year interval: 11 to 20,21 to 30,31 to 40,41 to 50,51 to 60,61 to 70 , and $\geq 71$ years.

Data analysis were performed by using the SPSS program (version 22.0, SPSS Inc.,Chicago, IL, USA).The results were expressed as means and standard deviation for quantitative variables, and numbers and frequency for qualitative variables. Only results from the right eyes were used for the analysis. Spearman's correlation coefficient was used to evaluate the correlations between CCT and endothelial parameters with age. Multiple linear regressions were used to adjust the effects of gender and age with other dependent variables. The parameters were compared between the right and left eye by using pair t-test. A value of $P<0.05$ was considered statistically significant.

\section{Results}

A total of 1002 eyes from 501 normal volunteers were studied with a mean age of $43.12 \pm 18.80$ (range $11-88$ years). There were $347(69.3 \%$ ) females and $154(30.7 \%)$ males. The mean CCT in the study population was $533.80 \pm 33.00 \mu \mathrm{m}$. The mean ECD, CV, CA, and hexagonality were $2,732.48 \pm 258.51 \mathrm{cell} / \mathrm{mm}{ }^{2}$, $37.61 \pm 6.66 \%, 369.04 \pm 37.90 \mu \mathrm{m}^{2}$, and $49.03 \pm 7.53 \%$, respectively (Table 1 ).

There were significantly inversed correlations between ECD and CCT with increased age $(r-0.212, p<0.001$ and $r-0.484, p<0.001$, respectively) (Fig. $1 A$ and $2 A)$. While the $C V$ and $C A$ had significantly direct correlation with increase aging $(r=0.200, p<0.001$ and $r=0.475, p<0.001$, respectively) (Fig. 1B, C). The percentage of hexagonality showed significant decrease with ages $(r=-0.193, p<0.001$ (Fig. 1D).

When age was adjusted for the correlation between gender and corneal morphology by using multiple regression analysis, males had a significant inverse correlation with CV $(B=-2.93, p<0.001)$ and direct correlation with hexagonality $(B=4.99, P<0.001)($ Table 2$)$. From single linear regression, an expected ECD for each age can be calculated using the equation; $y=a+b x$.

If: $y=$ endothelial cell density, $x=$ age, $a=3026.53$, and $b=-6.819$

By using this equation, the estimated annual endothelial cell loss rate in normal Thai eyes is $0.225 \%$.

When the CCT and other corneal endothelial parameters were compared between eyes, only mean CCT was significantly different between the right and left eyes (Table 3). The relationship between CCT and ECD was directly correlated $(r=0.177, p<0.001)$ (Fig. 2B).

Table 1:Corneal thickness and endothelial morphology of study population in different age groups

\begin{tabular}{|lllllll|}
\hline Age (years) & Number (eyes) & $\begin{array}{l}\text { CCT } \\
(\mu \mathrm{m})\end{array}$ & $\begin{array}{l}\text { CD } \\
\left(\text { cell/ } \mathrm{mm}^{2}\right)\end{array}$ & $\begin{array}{l}\text { CV } \\
(\%)\end{array}$ & $\begin{array}{l}\text { CA } \\
\left(\mu \mathrm{m}^{2}\right)\end{array}$ & $\begin{array}{l}\text { Hexagonality } \\
(\%)\end{array}$ \\
\hline $11-20$ & 72 & $547.40 \pm 36.84$ & $2944.65 \pm 231.95$ & $34.76 \pm 5.87$ & $341.71 \pm 27.02$ & $54.06 \pm 10.12$ \\
\hline $21-30$ & 88 & $533.62 \pm 32.07$ & $2843.08 \pm 193.29$ & $36.25 \pm 4.42$ & $353.23 \pm 23.26$ & $50.00 \pm 7.92$ \\
\hline $31-40$ & 70 & $536.44 \pm 28.88$ & $2777.23 \pm 206.59$ & $37.99 \pm 4.75$ & $361.97 \pm 26.93$ & $47.74 \pm 5.32$ \\
\hline $41-50$ & 73 & $539.90 \pm 30.24$ & $2686.05 \pm 234.18$ & $37.56 \pm 4.87$ & $375.25 \pm 34.17$ & $47.30 \pm 5.60$ \\
\hline $51-60$ & 87 & $530.62 \pm 32.91$ & $2650.80 \pm 178.81$ & $38.41 \pm 7.06$ & $377.89 \pm 28.91$ & $48.40 \pm 6.45$ \\
\hline $61-70$ & 82 & $521.74 \pm 32.70$ & $2581.67 \pm 269.58$ & $39.77 \pm 9.98$ & $391.17 \pm 48.38$ & $48.17 \pm 6.16$ \\
\hline $71-80$ & 29 & $522.52 \pm 28.26$ & $2550.45 \pm 315.72$ & $39.45 \pm 6.29$ & $397.28 \pm 50.54$ & $45.38 \pm 8.54$ \\
\hline Total & 501 & $533.80 \pm 33.00$ & $2732.48 \pm 258.51$ & $37.61 \pm 6.66$ & $369.04 \pm 37.90$ & $49.03 \pm 7.53$ \\
\hline CCT: central corneal thickness, ECD: endothelial cell density, & & & & \\
\hline CV: coefficient of variation in cell size, CA: cell area & & & & \\
\hline
\end{tabular}

Table 2:Multiple linear regression analysis for central corneal thickness and corneal endothelial parameters

\begin{tabular}{|llllllllllll|}
\hline & CCT & \multicolumn{3}{c}{ ECD } & & CV & & CA & & Hexagonality \\
\cline { 2 - 11 } & B & p-value & B & p-value & B & p-value & B & p-value & B & p-value \\
\hline $\begin{array}{l}\text { Sex } \\
\text { (Male to Female) }\end{array}$ & -0.043 & 0.989 & 29.973 & 0.172 & -2.926 & $<0.001$ & -4.021 & 0.219 & 4.999 & $<0.001$ \\
\hline Age (year) & -0.378 & $<0.001$ & -6.722 & $<0.001$ & 0.076 & $<0.001$ & 0.934 & $<0.001$ & -0.090 & $<0.001$ \\
\hline B: Beta coefficient, CCT: central corneal thickness, ECD: endothelial cell density, & & & & & \\
\hline CV: coefficient of variation in cell size, CA: cell area & & & & & & & \\
\hline
\end{tabular}


Table 3: Comparison of the central corneal thickness and corneal endothelial morphology between eyes

\begin{tabular}{|llll|}
\hline $\begin{array}{l}\text { Variable } \\
(\text { mean } \pm \text { SD })\end{array}$ & $\begin{array}{l}\text { Right eye } \\
(\mathbf{n}=\mathbf{5 0 1})\end{array}$ & $\begin{array}{l}\text { Left eye } \\
(\mathbf{n}=\mathbf{5 0 1})\end{array}$ & p-value \\
\hline $\mathrm{CCT}(\mu \mathrm{m})$ & $533.80 \pm 33.00$ & $523.27 \pm 32.43$ & $<0.0001$ \\
\hline $\mathrm{ECD}\left(\mathrm{cell} / \mathrm{mm}^{2}\right)$ & $2732.48 \pm 258.51$ & $2730.21 \pm 251.07$ & 0.681 \\
\hline $\mathrm{CV}(\%)$ & $37.61 \pm 6.66$ & $37.69 \pm 14.48$ & 0.901 \\
\hline $\mathrm{CA}\left(\mu \mathrm{m}^{2}\right)$ & $369.04 \pm 37.90$ & $369.69 \pm 38.05$ & 0.500 \\
\hline Hexagonality $(\%)$ & $49.03 \pm 7.53$ & $48.57 \pm 7.56$ & 0.074 \\
\hline CCT: central corneal thickness, ECD: endothelial cell density, & \\
\hline CV: coefficient of variation in cell size, CA: cell area & \\
\hline
\end{tabular}

Table 4:Literature review of studies of corneal endothelial morphology and corneal thickness among various populations 


\begin{tabular}{|c|c|c|c|c|c|c|c|c|c|c|c|}
\hline \multirow[t]{2}{*}{ Study } & \multirow[t]{2}{*}{ Population } & \multirow[t]{2}{*}{$\begin{array}{c}\mathrm{N} \\
\text { (eyes/cases) }\end{array}$} & \multirow{2}{*}{$\begin{array}{c}\text { Mean Age } \\
\text { (range), } \\
\text { years }\end{array}$} & \multirow[t]{2}{*}{ Machines } & \multirow{2}{*}{$\begin{array}{c}\text { Mean } \\
\text { ECD } \\
\text { (cell/mm) }\end{array}$} & \multirow{2}{*}{$\begin{array}{l}\text { Cell } \\
\text { loss } \\
\text { rate } \\
(\%) / \\
\text { year }\end{array}$} & \multicolumn{2}{|c|}{$\begin{array}{l}\text { Correlation: } \\
\text { ECD and Age }\end{array}$} & \multirow[t]{2}{*}{$\begin{array}{c}\text { Mean CCT } \\
(\mathrm{mm})\end{array}$} & \multicolumn{2}{|c|}{$\begin{array}{l}\text { Correlation: } \\
\text { CCT and Age }\end{array}$} \\
\hline & & & & & & & $r$ & $\begin{array}{c}\mathrm{p}- \\
\text { value }\end{array}$ & & $r$ & $\begin{array}{c}\mathrm{p}- \\
\text { value }\end{array}$ \\
\hline $\begin{array}{l}\text { Rao et al. } \\
2000[16]\end{array}$ & Indian & $1074 / 537$ & $\begin{array}{l}48 \pm 16.5 \\
(20-87)\end{array}$ & $\begin{array}{l}\text { KonanSP8000, } \\
\text { USP(for CCT) }\end{array}$ & $2525 \pm 337$ & 0.3 & -0.387 & $<0.001$ & $533 \pm 50 *$ & - & - \\
\hline $\begin{array}{l}\text { Padilla et al. } \\
2004 \text { [11] }\end{array}$ & Filipino & $640 / 360$ & $\begin{array}{l}53 \pm 17 \\
(20-86)\end{array}$ & KonanP9000 & $2798 \pm 307$ & - & -0.21 & NA & - & - & - \\
\hline $\begin{array}{l}\text { Hashemian } \\
\text { et al. } \\
2006 \text { [19] }\end{array}$ & Iranian & $\begin{array}{l}525 / 525 \\
\text { Only OD }\end{array}$ & $\begin{array}{l}52.7 \pm 19.1 \\
(20-80)\end{array}$ & TopconSP2000 & $1961 \pm 457$ & 0.6 & -0.64 & $<0.001$ & - & - & - \\
\hline $\begin{array}{l}\text { Yunliang et } \\
\text { al. } \\
2007 \text { [18] }\end{array}$ & Chinese & $1329 / 700$ & $\begin{array}{l}44 \pm 21 \\
(10-98)\end{array}$ & KonanSP9000 & $2932 \pm 363$ & 0.3 & -0.435 & 0.001 & - & - & - \\
\hline $\begin{array}{l}\text { Niederer et } \\
\text { al. } \\
2007 \text { [22] }\end{array}$ & $\begin{array}{l}\text { New } \\
\text { Zealand }\end{array}$ & $85 /$ NA & $\begin{array}{l}38 \pm 16 \\
(18-87)\end{array}$ & $\begin{array}{l}\text { HRT II Rostock } \\
\text { Corneal } \\
\text { Module }\end{array}$ & $2720 \pm 367$ & 0.5 & -0.615 & $<0.001$ & $555 \pm 31$ & 0.148 & 0.176 \\
\hline $\begin{array}{l}\text { Higa et al. } \\
2010 \text { [17] }\end{array}$ & Japanese & $3762 / 4714$ & $\begin{array}{l}59.1 \pm 14.9 \\
(>40)\end{array}$ & TopconSP2000 & $2943 \pm 387$ & 0.25 & -0.34 & $<0.001$ & NA & - & - \\
\hline $\begin{array}{l}\text { Mohammad- } \\
\text { Salih et al. } \\
2011 \text { [12] }\end{array}$ & Malay & $125 / 125$ & $\begin{array}{l}45.8 \pm 20.7 \\
(20-87)\end{array}$ & TopconSP3000 & $2648 \pm 310$ & - & -0.300 & 0.001 & - & - & - \\
\hline $\begin{array}{l}\text { Galgauska } \\
\text { et al. } \\
2013 \text { [23] }\end{array}$ & Lithuania & $358 / 211$ & $\begin{array}{l}\text { NA } \\
(20-89)\end{array}$ & KonanSP9000 & $\begin{array}{l}2931 \pm 371 \\
* * \text { to } \\
\underset{* * *}{2222 \pm 182}\end{array}$ & - & -0.650 & 0.01 & $\begin{array}{l}563 \pm 44^{*} \text { to } \\
540 \pm 35^{\star \star}\end{array}$ & -0.156 & 0.01 \\
\hline $\begin{array}{l}\text { Arici et al. } \\
2014 \text { [13] }\end{array}$ & Turkish & $252 / 126$ & $\begin{array}{l}44.3 \pm 13.5 \\
(20-70)\end{array}$ & TopconSP3000 & $2732 \pm 305$ & $\begin{array}{l}1.9- \\
5.9\end{array}$ & -0.388 & $<0.001$ & $521 \pm 33$ & -0.241 & $<0.001$ \\
\hline $\begin{array}{l}\text { Ewete et al. } \\
2016 \text { [15] }\end{array}$ & Nigerian & $359 / 201$ & $\begin{array}{l}50.35 \pm 20.13 \\
(20-93)\end{array}$ & Konan SP9000 & $2610 \pm 371$ & - & -0.318 & $<0.001$ & - & - & - \\
\hline $\begin{array}{l}\text { Abdellah et } \\
\text { al. } \\
2019 \text { [14] }\end{array}$ & Egyptian & $568 / 568$ & $\begin{array}{l}49 \pm 15.2 \\
(20-85)\end{array}$ & Topcon SP-IP & $2647 \pm 387$ & 0.3 & -0.357 & $<0.001$ & $514 \pm 43$ & -0.133 & 0.007 \\
\hline This study & Thai & $\begin{array}{l}\text { 1002/501 } \\
\text { Only OD }\end{array}$ & $\begin{array}{l}43.12 \pm 18.80 \\
(11-88)\end{array}$ & TomeyEM4000 & $2732 \pm 258$ & 0.225 & -0.484 & $<0.001$ & $533 \pm 33$ & -0.212 & $<0.001$ \\
\hline
\end{tabular}

ECD: endothelial cell density,CCT: central corneal thickness, USP: ultrasound pachymeter,

* CCT decreased with age but not statistically significant, **age 20-29 years old, *** age 80-89 years old

\section{Discussion}

This study demonstrated that the corneal endothelial cell density and the central corneal thickness decreased with aging. Although the corneal endothelial cell density and other morphology have been reported in previous studies, direct comparison of the results among studies is limited due to various evaluation methods and study populations. The results from most studies showed a trend toward decreasing cell density (Table 4) and increasing cell variation with aging. High CEC density $\left(>4200\right.$ cells $/ \mathrm{mm}^{2}$ ) had been reported just after birth and in infants, but these values rapidly decreased during childhood and then decreased slowly after the age of 18 [10]. This evidence supports the fact that corneal endothelium lacks proliferative ability, resulting in reduction of these cells with age.

$$
\begin{gathered}
\text { Table } \\
4
\end{gathered}
$$

The mean ECD in this study was $2732 \pm 258 \mathrm{cell} / \mathrm{mm}^{2}$, which was similar to the results from other studies using non-contact specular microscope in normal eyes (Table 4). These included Filipino (2798 \pm 307) [11], Malay (2648 \pm 310$)$ [12], Turkish (2732 \pm 307$)$ [13], Egyptian (2647 \pm 387$)$ [14], Nigerian (2610 \pm 371$)$ [15], and Indian(2525 \pm 337$)$ [16]. The mean ECD in Thai eyes was lower than those of Japanese (2943 \pm 387$)$ [17] and Chinese (2932 \pm 363$)$ [18], but higher 
than the results of Iranian(1961 \pm 457$)$ [19]. The corneal diameter has been postulated to responsible for the variation of ECD in various populations as the corneal diameter might be inversely proportional to endothelial cell density as the Indian and American had less ECD than the Japanese people [16, 20]. However, one study using the confocal microscopy and the Orbscan machine did not find the correlation between ECD and corneal diameter in the elderly eyes [21]. The different results among studies could be due to the different specular microscope used in each study as well.

The annual endothelial cell loss rate in this study was $0.23 \%$, which was similar to the results in Chinese(0.3\%) [18], Indian (0.3\%) [16], Egyptian (0.3\%) [14], and Japanese (0.25\%) [17], while this was lower than those from the Middle East and Caucasians i.e. Iran (0.6\%) [19]. Yunling et al. reported the annual cell loss of $0.3 \%$ in a normal Chinese population [18]. However, they noted a variation in the cell loss rate in different age groups with a higher loss of cells in the younger age groups. They also suggested that an exponential function to determine the rate of cell loss might be more appropriate than using linear regression analysis. Niederer et al. used in vivo confocal microscopy with contact method for studying corneal morphology and found that the annual rate of CEC cell loss was $0.5 \%$ [22].

Aging also influenced other corneal parameters. This study found that age had a direct correlation with the variation of cell size and cell area, and had an inverse correlation with hexagonality. The negative impacts of age on the cell variation (Indian, Chinese, Malay, Filipino) [11, 12, 16, 18], cell size (Malay, Chinese, Indian, Iranian, Turkish, Filipino) $[11-13,16,18,19]$ and cell shape(Indian, Chinese, Turkish) $[13,16,18]$ were previously reported from different study populations. One study in Lithuania did not show the correlation of age on the CV and hexagonality [23].

For the influence of gender on CECs, after adjustment for age this study found that males had a significant inverse correlation with CV and direct correlation with hexagonality. This means that CECs in males are supposed to have less variable in size and had more hexagonal shape than in females. These findings were different from studies in the Filipino [11] and Japanese population [17], in which women had significantly greater ECD than that in men. Some studies including Malay [12], Turkish [13], Iranian [19], and Egyptian [14] found no significant differences of mean ECD between genders.

Corneal thickness, another important indicator of corneal health and changes in corneal endothelial function, becomes more important in determining the IOP and in planning for refractive surgery. In general, the cornea becomes edematous if the CECs decrease or loss of function. This study demonstrated that the CCT decreased with increasing age and this was similar to studies in Lithuania [23], Turkish [13] and Egyptian [14] populations (Table 4). Müller et al. investigated the ECD and corneal thickness in different areas of the cornea in elderly eyes using the confocal microscopy and corneal topography (Orbscan II). They found that ECD significantly correlated with CCT and corneal curvature [21]. They suggested that in an older population, low ECD values would be expected in thinner and /or steeper cornea. Results from a population-based study in Japan, using the ultrasound pachymeter (USP) for evaluating the CCT in adult volunteers (age more than 40), found that CCT significantly correlated with ECD even though they suggested that the results may not be clinically significant $(r=0.071)$ [17]. The USP is a frequently used pachymeter, however, the main disadvantage of this device is the variation among examiners due to the inaccuracy of the probe alignment causing errors in measurement [24]. This present study used the non-contact specular microscopy that could assess both the corneal endothelial morphology and the central corneal thickness. This non-contact device has advantages of reducing the risk of corneal epithelial injury, transmission of infection, artifacts resulting from corneal manipulation and also providing comfort for the patents. However, this present study did not investigate the ECD in different areas of the cornea as well as the relationship of corneal endothelium and other corneal parameters such as corneal diameter and curvature.

\section{Conclusion}

This study on corneal endothelial morphology in the Thai population showed that central corneal thickness, endothelial cell density, and hexagonality were significantly decreased, while cell size and cell variation were increased with aging. The central corneal thickness was correlated with the endothelial cell density. The results of this study can be used as normative data for further studies.

\section{Declarations}

\section{Ethics approval and consent to participate}

This study was approved from the Research and Ethics Committee of Faculty of Medicine, Chiang Mai University (Study code: OPT-2559-03823) and followed the tenets of Declaration of Helsinki. Written informed consent was obtained from all the participants and from a parent or guardian for participants under 16 years old after complete explanation.

\section{Consent for publication}

Not applicable.

\section{Funding}

This work was supported by the Faculty of Medicine Endowment Fund, Faculty of Medicine, Chiang Mai University (Grant Number: 120/2559). The funder had no role in study design, data collection and analysis, decision to publish, or preparation of the manuscript.

\section{Competing interests}

The authors have declared that no competing interests exist.

\section{Availability of data and materials}


The datasets used and/or analysed during the current study available from the corresponding author on reasonable request.

Authors information

Affliation

Department of Ophthalmology, Faculty of Medicine, Chiang Mai University, Chiang Mai, Thailand

\section{Corresponding author}

Napaporn Tananuvat, M.D.

Department of Ophthalmology, Faculty of Medicine, Chiang Mai University

Chiang Mai, Thailand, 50200 Email: ntananuvat@gmail.com

Tel:66 53 935512, Fax:66 53936121

\section{Authors' contributions}

NT made a substantial contribution to conception and design, participate in data acquisition, data analysis and interpretation, revising the manuscript. NK was involved in study conception and design, participate in data acquisition, data analysis and interpretation, and drafting the manuscript. All authors read and approved the final manuscript.

\section{Acknowledgements}

The authors would like to thank Associate Professor Janejit Choovuthayakorn, M.D. (Department of Ophthalmology, Faculty of Medicine, Chiang Mai University) and Ms. Rochana Pheukjunteuk for their kind assistance in statistical analysis.

\section{Abbreviations}

CA: cell area

CCT: central corneal thickness

CECs: Corneal endothelial cells

$\mathrm{CV}$ : coefficient of variation in cell size

ECD: endothelial cell density

IOP: intraocular pressure

USP: ultrasound pachymeter

VA: visual acuity

\section{References}

1. Waring GO,3rd, Bourne WM, Edelhauser HF, Kenyon KR: The comeal endothelium. Normal and pathologic structure and function. Ophthalmology 1982; 89:531-90.

2. Mishima S: Clinical investigations on the corneal endothelium-XXXVIII Edward Jackson Memorial Lecture. Am J Ophthalmo/ 1982; 93:1-29.

3. Bourne WM, McLaren JW: Clinical responses of the corneal endothelium. Exp Eye Res 2004; 78:561-72.

4. Rosado-Adames N, Afshari NA: The changing fate of the comeal endothelium in cataract surgery. Curr Opin Ophthalmol 2012; 23:3-6.

5. Liesegang TJ: Physiologic changes of the comea with contact lens wear. CLAO J 2002; 28:12-27.

6. Kheirkhah A, Saboo US, Abud TB, Dohlman TH, Arnoldner MA, Hamrah P, Dana R: Reduced Corneal Endothelial Cell Density in Patients With Dry Eye Disease. Am J Ophthalmol 2015; 159:1022-6 e2.

7. Sudhir RR, Raman R, Sharma T: Changes in the comeal endothelial cell density and morphology in patients with type 2 diabetes mellitus: a populationbased study, Sankara Nethralaya Diabetic Retinopathy and Molecular Genetics Study (SN-DREAMS, Report 23). Cornea 2012; 31:1119-22.

8. Nishida T: In: Krachmer J, ed. Cornea Vol. 1 Fundamentals of cornea and external disease. St. Louis : Mosby, 1997:17-19.

9. Doughty MJ, Zaman ML: Human comeal thickness and its impact on intraocular pressure measures: a review and meta-analysis approach. Surv Ophthalmol 2000; 44:367-408. 
10. Muller A, Doughty MJ, Wright L: Reassessment of the corneal endothelial cell organisation in children. Br J Ophthalmol 2000; 84:692-6.

11. Padilla MD, Sibayan SA, Gonzales CS: Corneal endothelial cell density and morphology in normal Filipino eyes. Cornea 2004; 23:129-35.

12. Mohammad-Salih PA: Corneal endothelial cell density and morphology in normal Malay eyes. Med J Malaysia 2011; 66:300-3.

13. Arici C, Arslan OS, Dikkaya F: Comeal endothelial cell density and morphology in healthy Turkish eyes. J Ophthalmol 2014; 2014:852624.

14. Abdellah MM, Ammar HG, Anbar M, Mostafa EM, Farouk MM, Sayed K, Alsmman AH, Elghobaier MG: Comeal Endothelial Cell Density and Morphology in Healthy Egyptian Eyes. J Ophthalmol 2019; 2019:6370241.

15. Ewete T, Ani EU, Alabi AS: Normal corneal endothelial cell density in Nigerians. Clin Ophthalmo/ 2016; 10:497-501.

16. Rao SK, Ranjan Sen P, Fogla R, Gangadharan S, Padmanabhan P, Badrinath SS: Corneal endothelial cell density and morphology in normal Indian eyes. Cornea 2000; 19:820-3.

17. Higa A, Sakai H, Sawaguchi S, Iwase A, Tomidokoro A, Amano S, Araie M: Corneal endothelial cell density and associated factors in a population-based study in Japan: the Kumejima study. Am J Ophthalmo/ 2010; 149:794-9.

18. Yunliang S, Yuqiang H, Ying-Peng L, Ming-Zhi Z, Lam DS, Rao SK: Corneal endothelial cell density and morphology in healthy Chinese eyes. Cornea 2007; 26:130-2.

19. Hashemian MN, Moghimi S, Fard MA, Fallah MR, Mansouri MR: Comeal endothelial cell density and morphology in normal Iranian eyes. BMC Ophthalmol $2006 ; 6: 9$.

20. Matsuda M, Yee RW, Edelhauser HF: Comparison of the comeal endothelium in an American and a Japanese population. Arch Ophthalmo/ 1985; 103:6870 .

21. Muller A, Craig JP, Grupcheva CN, McGhee CN: The effects of comeal parameters on the assessment of endothelial cell density in the elderly eye. Br J Ophthalmol 2004; 88:325-30.

22. Niederer RL, Perumal D, Sherwin T, McGhee CN: Age-related differences in the normal human comea: a laser scanning in vivo confocal microscopy study. Br J Ophthalmo/ 2007; 91:1165-9.

23. Galgauskas S, Norvydaite D, Krasauskaite D, Stech S, Asoklis RS: Age-related changes in corneal thickness and endothelial characteristics. Clin Interv Aging 2013; 8:1445-50.

24. Al Farhan HM, Al Otaibi WM, Al Razqan HM, Al Harqan AA: Assessment of central comeal thickness and corneal endothelial morphology using ultrasound pachymetry, non-contact specular microscopy, and Confoscan 4 confocal microscopy. BMC Ophthalmol 2013; 13:73.

\section{Figures}



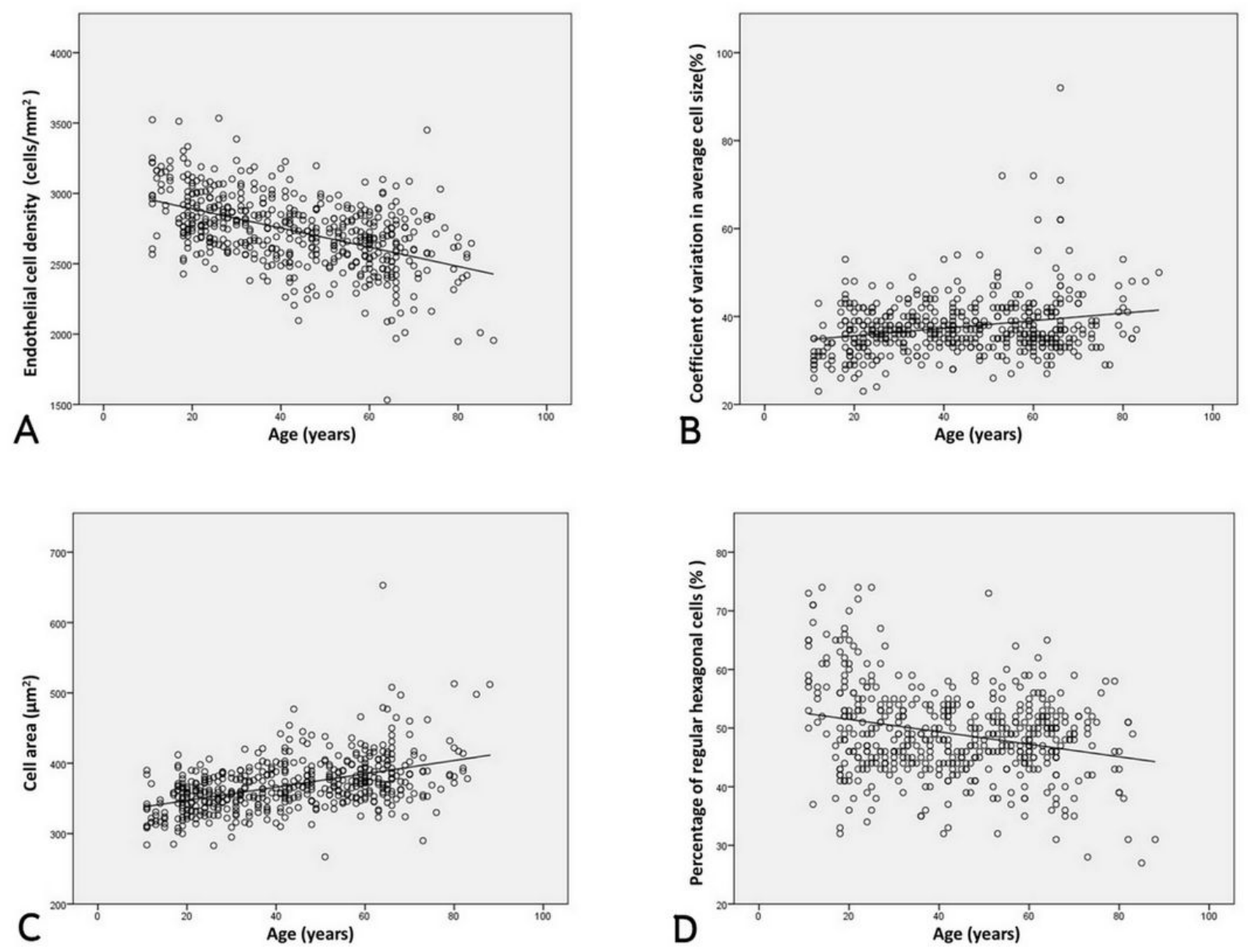

\section{Figure 1}

Scatter plots show the correlation between age and the endothelial cell density (A), coefficient of variation in average cell size (B), cell area (C), and percentage of regular hexagonal cells (D).
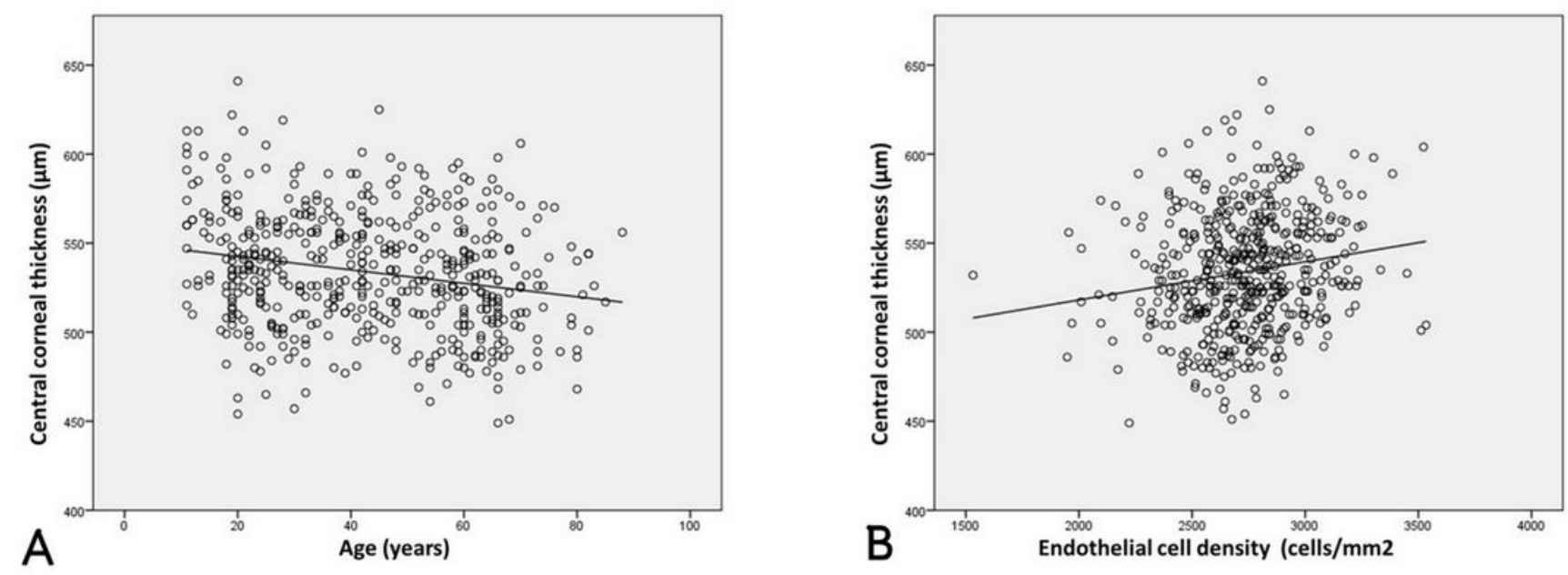

\section{Figure 2}

Scatter plots show the correlation between the central corneal thickness and age (A), and the endothelial cell density (B). 